\title{
The (Co-)Construction of Knowledge within Initial Teacher Training: Experiences from Croatia ${ }^{1}$
}

LidiJA VujičIĆ ${ }^{\star 2}, \check{Z ̆ E L J K O ~ B o n e T A ~}^{3}$, AND ŽELJKA IvKOVIĆ ${ }^{4}$

$\approx$ "Learning by doing" within and together with a "community that learns" ought to become the fundamental method of learning - not only for children, but also for their teachers and other participants in the educational process. To what extent are students of early and preschool education involved in such work methods, and what have their experiences been like? An example of a research-based, reflective approach to practice grounded in action research and the co-construction of knowledge with students shall be presented as an example of quality practice at the Faculty of Teacher Education in Rijeka. Such a form of practice creates knowledge through the action itself and through contemplation of one's actions and the actions of others, all with the purpose of strengthening the practical competencies of future teachers. Our conclusion is that mutual learning, as propounded by the social constructivist approach to education, within the context of the mutual discussions between students and teachers that we organized directly contributed to the development of (self-)reflection competencies among future teachers, while also immersing all participants in an environment conducive to deliberation and the (re)definition of oneself and one's own pedagogical work.

Keywords: initial teacher training, professional development, reflective practitioners, (self-) reflection, the (co-)construction of knowledge

1 This work has been fully supported by the University of Rijeka under project number [13.10.2.2.01].

$2{ }^{\star}$ Corresponding Author. University of Rijeka, Faculty of Teacher Education, Croatia; lidija@ufri.hr

3 University of Rijeka, Faculty of Teacher Education, Croatia

4 University of Rijeka, Faculty of Teacher Education, Croatia 


\section{(So)ustvarjanje znanja v začetnem izobraževanju učiteljev: izkušnje iz Hrvaške ${ }^{5}$}

Lidija Vujičić* ${ }^{*}$ ŽELJKo Boneta IN ŽELJKA IvKović

$\curvearrowright$ "Učenje z delom « znotraj in skupaj z »učečo se skupnostjo « bi morala postati temeljna metoda učenja - ne samo za otroke, ampak tudi za njihove učitelje in druge udeležence v izobraževalnem procesu. V kolikšni meri so študentje zgodnjega in predšolskega izobraževanja vključeni v tovrstno metodo dela in kakšne so njihove izkušnje? Predstavili bomo primer raziskovalno zasnovanega, reflektivnega pristopa $\mathrm{k}$ praksi, temelječega na akcijski raziskavi, in soustvarjanje znanja s študenti kot primer kakovostne prakse na Pedagoški fakulteti na Reki. Tak način dela ustvarja znanje že prek same aktivnosti pa tudi prek razmisleka o lastni aktivnosti ter aktivnosti drugih $\mathrm{z}$ namenom krepitve praktičnih kompetenc bodočih učiteljev. Naša temeljna ugotovitev je, da je vzajemno učenje, kot je opredeljeno v socialno konstruktivističnem pristopu k izobraževanju, ki smo ga organizirali v obliki skupnih diskusij med študenti in učitelji, neposredno prispevalo $\mathrm{k}$ razvoju (samo)refleksivnih kompetenc bodočih učiteljev. Poleg tega je bilo ustvarjeno okolje, ki je vodilo in spodbujalo vse udeležence $\mathrm{k}$ razpravljanju ter (re)definiranju samih sebe in svojega pedagoškega dela.

Ključne besede: začetno izobraževanje učiteljev, profesionalni razvoj, razmišljajoči praktiki, (samo)refleksija, (so)ustvarjanje znanja 


\section{Starting points}

The central thesis of our work rests on our view of teacher training as a strategy within which initial training is understood as a fundamental part of future professional development. Such a strategy implies the necessity of a paradigm shift in the institutional cultures of teacher-training colleges, as well as within the education system in general. We wish to emphasize that, in addition to planning and developing curricula for initial teacher training, these changes are all-encompassing in nature and also imply a different form of relationship between teachers and students: cooperative relationships based on two-way communication and reciprocity and grounded in the mutual learning of all participants. Therefore, all social actors within the community at large are involved in an established, research-oriented, developmental and mutual learning process that aims to develop one of the key competencies in modern education: the competency for lifelong learning. In other words, initial teacher training is but a part of one comprehensive system of professional development. Its task is to qualify and prepare teachers for the vocation they have selected, but also to prepare them for further professionalization and the process of continued personal growth that begins with initial training and ends with the final cessation of employment. In this manner, a vision of professional development is created that aims to train educators skilled in reflection and evaluation of the educational process, who are able to think critically and ensure the prerequisites for the development of each child (Vujičić \& Miketek, 2014). In order to successfully adopt this new role, the modern educator is expected to be open to change, motivated for lifelong learning and researching their own practice, and to be able to develop a culture of dialogue and cooperation in order to achieve the best and most efficient professional development possible. Consequently, we hold that an education grounded in a social constructivist approach represents a significant step forward in preparing students for the complexity and unpredictability of practice (i.e. their future roles as teachers and self-reflective practitioners), as it involves processes of active learning, direct research and understanding through reflective practice (Rinaldi, 2006; Dalhberg \& Moss, 2006).

We wish to emphasize that, apart from a different view of children, childhood and early education institutions, the social constructivist approach also assigns teachers a role that is significantly more complex and requires greater responsibility, while also presupposing a new mode of initial training, learning and professional development. We advocate a teacher-training model based on reflective practice (Schoen, 1990; Elliot, 1998, et al.), in which central importance is given to students as future teachers and professionals whose education is 
grounded in research. This model is rooted in a holistic paradigm and views educational as a social and dialogic process that unfolds through interaction, discussion and exchange (Bruner, 2000). Learning by doing and exploring together with other participants in the education process (other students, professors, teachers and practitioners) is in accordance with a social constructivist approach that, according to Beck and Kosnik (2006), implies a form of learning in which students are fully active and free to discover the purpose of the process themselves, thus participating in the construction of their knowledge and forming habits that mould them into lifelong learners. Zaclona (2007) holds that universities that train future teachers have the necessary role of creating situations and strengthening experiences that give students the chance to reflect upon themselves and their educational reality. In this sense, university programmes rooted in a social constructivist approach imply the training of students through action research, i.e. their participation in research as part of their practice (Vujičić \& Đapić, 2009; Lepičnik-Vodopivec \& Vujičić, 2010). Such an approach motivates participants in action research (Mac Naughton \& Hughes, 2009) to modify their roles and take responsibility, thus creating a teacher-researcher that will have a profound influence on changing educational practice.

According to Miljak, social constructivism is manifested in a transactional-transformational approach, according to which knowledge is viewed as: "[...] something that is constructed and reconstructed by those participating in the education process. The education process is viewed as a dialogue, as the interaction between teachers, students and the environment. The students play an active role in this process by constructing and reconstructing their knowledge, by which they change both themselves and their environment" (Miljak, 1996, p.18).

Through dialogue and discussion as the fundamental modes of learning within action research, students gain an awareness of the responsibility of the role of an educator of young children and achieve a level of confidence and self-awareness that allows them to explore new possibilities with children, thus attaining a meta-level of teaching, i.e. a feature of the most skilled practitioners and researchers (Vujičić, Tatalović Vorkapić, \& Boneta, 2012). As a result, the role of a teacher within a social constructivist approach to education based on action research is to organize discussions that students will perceive as pleasant and useful while respecting the individual differences that exist among students concerning their cooperation and communication skills. This ought to be a collegial discourse in which students are allowed to assume, ascertain, make mistakes and correct them: to put it briefly, to construct their pedagogical knowledge independently and in a group. 
In their research of study programmes in the USA and Australia, Beck and Kosnik (2006) stress the importance of action research, i.e. connecting theory and practice in order to create mutual knowledge, understanding and sense. In order to execute such a programme in a quality fashion, students need to be divided into smaller groups that are headed by a team of university teachers. Work in such learning teams allows for constant dialogue and cooperative learning, which gives students the opportunity for continued reflection and the development of their own ideas. The result of the operation of such "learning communities" grounded in social constructivism is a powerful feeling of camaraderie and a holistic learning experience that, in addition to social aspects, also encompasses emotional, aesthetic, physical and other forms of expression. Such an approach "not only allows for broad personal development, but ensures the depth of understanding and experience needed for knowledge construction" (Beck \& Kosnik, 2006, p. 13). In other words, knowledge is constructed through the negotiation of meaning, in which the differing perspectives of teachers and students do not exclude each other but, in contrast, supplement each other. This interaction between teachers and students/future teachers ought to be the central point of the education process. Students/future teachers are expected to step out of their roles of passive recipients of knowledge, those that accept and practice the skills necessary for working in education, and take an active role in their own learning. Within this context, the role of the teacher is to create the conditions necessary for developing the students' sense of responsibility and independence, and to satisfy the needs of the students with regards to the selection of content and learning styles (Besson, Huber, Mompoint-Gaillard, \& Rohmann, 2014). Creating an environment for learning and research also implies research on the part of the teachers, i.e. exploration of the learning and teaching of their students. As students often imitate the behaviour of their teachers in their own practice, the comportment of teachers and their relationship towards their students is of exceptional importance, for their actions will be mirrored in the personal, professional development of future teachers, their implicit and explicit approaches to teaching and learning and their relationships with children. This is precisely why "profound changes" are of such crucial importance (Senge et al., 2003) regarding mental models: the personal values of teachers are a prerequisite for examining and changing the values of students. Many other authors (Bruner, 2000; Stoll \& Fink, 2000; Fullan, 2007) hold the same stance regarding values and the necessity of bringing them to awareness and changing them, while stressing that a quality education always ought to consider the fundamental views of the teachers. Thus, the teachers of future educators today face new challenges, together with new standards, roles, demands and professional competencies. 


\section{Towards a reflective model of initial teacher training}

In contrast to the traditional practice of teacher training grounded in a transmission paradigm, the transformative process of professionalization (Miljak, 1996) presupposes educating teachers to conduct reflective practice, and thus transforming teachers into reflective practitioners. Such a conceptual and methodological approach to practice is rooted in action research as a method of teaching and learning. Many authors that have dealt with reflective practice consider it an approach that is opposed to the traditional model and the positivist education of practitioners (Bruner, 2000; Pešić, 2004; Radulović 2011). The reflective practitioner is an active individual that explores various possibilities for solving practical problems.

The reflective practitioner creates, that is, constructs a reflective practice based on his/her own deliberation upon it - both before and after activities and during action, which is the feature of a highly skilled (reflective) practitioner. The growth process of a reflective practitioner implies a process of elevating oneself to a meta-level of one's own educational actions, teaching and learning (Šagud, 2006, p.14).

The training of a reflective practitioner is most often linked to action research and a social constructivist approach to learning. Such a connection (in contrast to tradition) implies a great paradigm shift in the education of future teachers, i.e. from a traditional to a social constructivist mode. As an important feature among the key competencies, reflectiveness presupposes the use of metacognitive skills and creative and critical thinking. Reflective competencies are a product of development and growth, just like any other competency, while also demanding a proclivity for introspection, independence in scheduling activities, responsibility for one's own decisions and actions, and self-critique. One of the key elements in educating for reflective practice is practice itself, as only through practice can students discover the problems that are to become objects of reflection, develop reflection in action (attain empirical knowledge and experiences), test theoretical and empirical hypotheses, and seek new ways of understanding reality and constructing knowledge (Radulović, 2011).

The teacher as a reflective practitioner is viewed as an initiator of change, an impetus for learning that also takes care of his/her own personal and professional development. Elevating the level of knowledge and total competencies of future teachers requires the development of reflective abilities through a reflective education process. The commencement of a reflective process during initial 
training, which appears as a result of awareness and a responsibility for change, is a prerequisite for its continuation through further professional development and the establishment of "permanent learning strategies". The process of developing abilities through reflection presupposes opposition to routine, leadership, uniformity and rigidity and a predilection for independence, freedom, creativity and openness. It is precisely with this kind of approach to the education of future teachers (one that implies personal self-discovery and awareness instead of the mere accumulation of facts in order to improve knowledge) that it is possible to stimulate the re-examination of values and views and the "deconstruction of folk beliefs" (Bruner, 2000).

\section{Experiences from the Faculty of Teacher Education in Rijeka}

As part of its work in various courses (such as Reflective Practice, Documenting the Education Process, the Research and Knowledge-Based Integrated Curriculum, the Integrated Curriculum in Early and Preschool Education, CoConstruction of the Curriculum and others), the Faculty of Teacher Education in Rijeka has demonstrated a quality practice that advocates a social constructivist approach to the education of students while adhering to the characteristics of the "new" professional development of teachers. Emphasis is placed upon the participation of students in researching the realities of education, their active role in the processes of acquiring knowledge, building educational theories through mutual deliberation upon practice, and self-reflection and mutual reflection upon practice by working in small learning teams in cooperation with a teacher and education practitioners (Jančić-Komljen, 2013). We hold that such an approach to the education of students helps in preparing them for the demanding role of a (self-)reflective practitioner within the variable, complex and unpredictable context of educational practice.

In accordance with the aforementioned deliberations, we arrived at the following research question: to what extent does the manner in which future teachers are educated during their undergraduate university study (and, particularly, within the course the Research and Knowledge-Based Curriculum II) develop the competencies of a reflective practitioner among students? Likewise, we were interested in the extent to which the mutual group reflections conducted between students, education practitioners and teachers after the completion of individual practical activities that are part of the course assisted in the development of these competencies. The aims of the aforementioned course are focused on training students to gather and analyse data on the key factors, conditions 
and methodological procedures that are part of the education process in institutions for early and preschool education, while also stimulating them to conduct and deliberate upon the education process in a manner conducive to the holistic development of children and the satisfaction of their needs, their urge to explore and their desire to form theories derived from their natural curiosity.

The expected learning outcomes naturally emanated from these course aims and are as follows: self-evaluating and evaluating activities with children; developing a predilection for teamwork, cooperative learning, planning and executing various activities within an institutional context; critically evaluating diversity, i.e. social, physical and cognitive differences while planning, monitoring and interpreting children's activities; analysing the cognitive specificities of children with regard to observation, introducing changes, recognising and describing phenomena, analysing experiences and arriving to conclusions and implementing this knowledge in their leadership of the education process; comparing the selection of materials and activities to the abilities, skills and needs of the children; independently creating a written plan and preparing the appropriate didactical tools for conducting an education process that is in harmony with the nature of children; creating and conducting educational activities with children; analysing and evaluating educational activities.

\section{Methodology}

\section{Object and aim of research}

Our selection of an appropriate methodological approach was largely determined by the research matter itself, and we thus opted for a qualitative approach to research that possesses both a developmental and a research dimension and combines approaches that focus on the examination of its results, thus analysing both the students' achievements and growth (the development of competencies among students, with particular emphasis on reflection) while also monitoring the education process itself (the search for new paths, methods and approaches) and its future development. In this sense, our research project seeks answers to the following question that has posed by teachers: does the course the Research and Knowledge-Based Curriculum II, conceived in accordance with the aforementioned principles, possess the potential to stimulate reflection among students? Therefore, the aim of this study is to determine the contributions of this course to the development and training of students/future practitioners as reflective practitioners. Such learning not only occurs within a "practice-oriented community", but also involves other actors through mutual 
action, dialogue and the exchange of knowledge and values (both explicit and implicit ones). In this manner, the roles of the participants in the education process (teachers, students and the group) are constantly reconstructed and redefined during the process of teaching and learning.

During our research, particular attention has been paid to the effects of teamwork and its contribution to developing reflective skills among students, for the juxtaposition of old and new ideas, and the views of the individual and the others was a frequent occurrence in the social interaction within the teams. Teamwork is an essential part of the course strategy of the Research and Knowledge-Based Curriculum II as it stimulates cooperative learning, which is considered a prerequisite for the attainment of reflective practice.

The research object, together with the theoretical foundation upon which the course the Research and Knowledge-Based Curriculum II is based and our vision of the educator of the future (a reflective practitioner rooted in the social constructivist paradigm), determined our methodological approach. The training of reflective practitioners and the development of reflective practice is a relatively new methodological approach to practice that lies in stark contrast to the traditional model of teacher training, and is most commonly grounded in action research and an emancipatory approach to pedagogical research. Although it cannot be described as action research in the truest sense of the term, this study possesses elements typical of reflective practice: the direct empirical examination of different solutions and the mutual construction of knowledge, changes and improvements to practice, which indicates that it can definitely be described as "research in education" instead of "research on education" (Pešić, 2004). With the intent of supporting and developing reflective dialogue, our discussions with students strived to discover their personal knowledge and theories on active learning, bring the tenets that support their thinking and teaching to light, develop a model for reflective practice, teach them how to develop professional knowledge and use it to support reflection within the education process and upon it, encourage them to reflect upon active learning; and generate a model of efficient pedagogical practices pertaining to active learning (adapted from Powell, 2005) .

\section{Course of the research}

As part of the course, the students were given the task to independently conduct activities with children of an early and preschool age, for which they had previously prepared with a written plan. After conducting their activities, the students gathered in learning teams together with a teacher and an education 
practitioner to hold a discussion, i.e. mutual reflection upon the activities they had just conducted. It is important to note that each team comprised eight students, of which four conducted independent activities, while the other four actively observed their work through the use of photographs and videos. The instruments used to gather data were recordings of the mutual reflections and discussions, i.e. transcripts of the recordings (the use of reflective video methodology).

The questions posed to the students were open-ended and required elaborations and descriptions, thus the students' skilfulness at self-critique and reflection can be deduced from their answers. Two questions ("What did I learn about the children's knowledge, interests, abilities and preferences?", "Did I respect the children's initiatives and proposals?") were focused on the students' satisfaction of the children's needs and interests and their acknowledgement of their ideas, the responses to which indicate the students' opinions of children, what their image of them is like and whether this image was created on the basis of a reflective discussion and is subject to change. Another segment of the questions was devised in a manner that aimed to bring to light the students' (lack of) flexibility and readiness for changing their own ideas (Did I manage to achieve the aim of the activity? Was I flexible in conducting the activities - did I deviate from my plan in order to follow the natural course of activities? Were there any spontaneous activities?). Several questions pertained to the creation and preparation of didactical materials (Were the materials well-suited to the children and sufficiently stimulating?), observation and analysis of the children's activities (What were the children able to learn?) and the students' views about what they felt they were successful at, and what still needs to be worked on. The students' proclivity for critical, reflective dialogue can be deduced from their answers to the questions posed as part of the discussion.

The discussions lasted, on average, from 45 to 60 minutes. The teacher would initiate discussion with the question "What were you most successful at?" to which the students that conducted the activities responded one by one. Then the teacher would involve the student observers with the following questions: "Was there, according to your opinion, a sufficient amount of materials?", "Would you change anything?", "What would your role be? In which situations would you involve yourself the most?", "What did you like about your colleagues' activities?" "At what point would you join a certain activity?", "What would you change about the activities and actions of your colleagues?"

In the initial part of the research, the video recordings of the group meetings were reviewed, after which the recordings were transcribed. It is important to note that all of the mutual reflections were conducted by a smaller group (team), while the total number of students that participated in the research was 28 . 
Some of the questions that the teachers posed to the students repeated themselves in most of the discussions, so we grouped them into three categories according to their focus: 1) focus on the self-evaluation of one's own success ("How did the students feel before the activity?", "Which situations do you think you handled the best?", "Which moments made you feel insecure?", "What would you change?", etc.), 2) focus on the evaluation of the activity and the materials offered ("Were you able to realize what you had previously envisioned?", "Were there any spontaneous activities?", "Was there a sufficient amount of materials and were they diverse enough?", "Were the materials appropriate for the children?", etc.); (3) focus on the evaluation of success as pertaining to the children ("What did you discover about the children?", "What were the children able to learn from these activities?", "Which competencies were they able to acquire?").

For the needs of this work, we shall analyse the students' most frequent responses in the areas of self-evaluation and evaluation of the children.

\section{Results and discussion}

Almost all of the students that described how they felt before the activities began stated that their fear was largely connected to doubts about whether the children would be interested in the activities they had planned. Apart from their concern for the children's interest levels, one student also expressed her anxiety about not being able to cope with the possibility of children pushing and shoving: "At the beginning, I felt scared - will all of this work, what will it be like? Will the children push and shove asking to go first? I was wondering how I would deal with that..." The unpredictability of practice is a segment that all students ought to seriously consider as something they should prepare themselves for during their education. We hold that reflective practice and "returning to action" represents the best method of preparing for the complexity and unpredictability of educational practice.

One student expressed fear about his overwhelming focus on preparation: "I was quite focused on doing all of it 'by the book'. Actually, I was very afraid of preparation because I thought I had to stick to what I had written as much as possible". This example indicates the necessity and desirability of reflective discussions with students that aim to examine their theories on success at the activities, i.e. to determines whether the students view success as adhering to their plan, or whether success can be viewed through flexibility and adapting to the current interests and needs of children, as opposed to following a predetermined plan. 
One student linked her fear prior to the activities with the recording of the process: "Actually, I felt the worst when, in the corner of my eye, I noticed I was being filmed. Then I was like...oh my!" However, as only this one student expressed such fear in all the seven discussions, it seems reasonable to conclude that the majority of the students accepted the transparency of their actions, i.e. the recording of their professional growth and development.

It is important to emphasize that, after conducting their activities, the students linked their success precisely to their flexibility and their focus on the child. The following segments of conversation with the teacher that indicate this:

S2: I compared the pictures of the cows and then told them that story. Then one girl started talking, then I pretended to be the girl and she pretended to be the cow, while another girl was the mum...

T: That is good...all that ended up very well. It was evident that there was a lot of interest. The activity lasted for a long time. You adapted well; you listened to them. Do you think that you listened to them?

S2: Well, I think so. Whenever they had an idea, I immediately went with it. I didn't stick to what I had written in my plans but adapted to them... T: How did you stop the game?

S2: It was time for breakfast, so I told the children that the cow was hungry and asked them whether they were hungry, too. The children said that they were, but first they played at feeding the cow grass and then went off to eat.

T: Excellent

We consider it an important and positive thing that the students were able to recognize the interests of children while the "action" was unfolding, to apply their theoretical knowledge and to share their experiences with the group. Experiences that differ from the one given above also exist, and they will be presented in our analysis of the answer to the question "What was I not successful at?"

The teacher asked the question "What were you not successful at?" or "Where did you perceive difficulties?" during three out of seven discussions. Despite this question not being consistently asked during all the discussions, from the transcriptions it is evident that the students were able to openly discuss those situations that they considered unsuccessful and those that they were not able to handle while conducting their independent practical activities:

T: Where did you perceive difficulties?

$S_{3}$ : When I took out the clay...in the beginning, the table was full, and then suddenly everybody went their own way and I was left alone. At 
that moment, I felt a bit panicky for being abandoned like that, but then after a few minutes somebody came again.

$\mathrm{T}$ : What were you supposed to do if nobody came?

$S_{3}$ : Go to the centre where milk was being offered to have a look, and then come back...

T: Then they came back, and you continued. So, you think you weren't very good at that part.

$S_{3}$ : They didn't consider it a failure. But from my point of view, it looks different.

T: That's right. Every such game is a success for them if we see it as a success, if we perceive everything they do as a process of learning and getting to know the world around them - in this case, the process of counting, recognising shapes and colours ...

Everything they do in this sense is a success, another rung on the ladder of their development. That's how we see it. If we view it as a failure when they don't do a task the way we have planned it, then we are sending them the message that they are unsuccessful... and only then will they really be unsuccessful. So, what we have is a vision of what they could do, but whether they're actually going to do it is beyond our influence. The activities were good and stimulating, and the children were interested.

In one situation, a student stated how the only thing she would change would be the preparation of stimuli ("I would make them stronger"), while the teacher used follow-up questions to indirectly indicate to the student some other elements of her work she ought to think about:

T: ... Communication?

S2: I wasn't even aware I used diminutives until you told me. Good you noticed that. I don't usually have the habit of using babytalk or stuff like that. And then I asked myself - when? I wasn't even aware I said that at that moment.

T: Yes. I like to say these things at a certain moment, because they represent a chance to bring it to awareness and change your behaviour like that. Your colleagues have previously said that they find this useful.

This example highlights both the importance of the role of the teacher and the importance of discussion for the students. Only after several follow-up questions and some deliberation did the student become aware of her mistake, which is something she should keep in mind in the future.

The communication between the students and the children was the 
topic of conversation in five discussion groups, and the following questions were asked: "Did you ask the children enough questions?", "Are you satisfied with your communication with the children?", "How did you talk to them?", "Apart from asking questions, did you communicate with the children in any other way?"

Out of the total of seven mutual discussions, there were three in which the student observers were not involved at all, either by their own initiative or by the initiative of the teacher. In these cases, the bulk of the discussion unfolded between the teacher and the students that had conducted independent activities that same day. Our analyses ascertained that, in addition to the lack of involvement of the student observers, the interaction between all participants was also missing, particularly with regards to brainstorming solutions to problems. In order to transform reflective post-activity discussions into debates in the true sense of the word, we state that all the present students ought to be more involved so that new knowledge and new theories can be discovered through mutual deliberation.

We held that certain situations had the potential for stimulating quality discussion; however, this did not happen in the end. Instead of offering readymade solutions, we determined that it is precisely in those situations that the students need to be stimulated by the teachers to express their thoughts on the given problem.

The following example illustrates one of only two examples that occurred in all the seven discussions pertaining to the self-initiated involvement of a student observer in the discussion:

S2 (student observer): Now the question is whether to stop the activity and the children's interest and give them some other activity? Even if we don't carry out what we have planned, I think it doesn't really matter.

$\mathrm{T}$ : Well observed.

S2: It makes no sense to stop something if it interests them.

T: Yes, what our colleague here says makes sense... on the other hand, it's also understandable that you wanted to see the children's reaction to this picture book, since a lot of effort was put into it. And into that doll, which was very good and motivating.

Our analysis of the transcripts determined that the students demonstrated self-critique while deliberating upon their own actions, along with a readiness to openly debate their thoughts and actions and to change their theories. However, regarding the part in which the student observers were supposed to give a critical review of the work of their colleagues, in all examples but one 
the students were very satisfied and had no remarks. We wonder whether the true reason for their compliments was indeed the fact that they did not notice anything that could be improved or perhaps whether their praise was motivated by student solidarity.

In any case, we hold that it is necessary to work more intensely on the development of students' reflective competencies in their further education, especially in regard to being critical towards others and not being afraid to openly address issues, as this is solely for the benefit of all participants and their professional development. From this segment of the analysis, it is evident that the discussions were dominated by the teacher and the students that had conducted the activity. The student observers were insufficiently involved even though their involvement is very feasible, particularly in small groups of eight students. We believe that these are valuable situations in which more work should be invested in order to develop optimal methods for monitoring and stimulating students to openly debate issues with their colleagues.

We wish to present an example that illustrates how the teacher stressed the importance of adapting to the children's interests instead of strictly following one's ideas and written plan. In this manner, the teacher motivated the student to think about her actions in a critical and reflective manner.

S: [...] Mara came to my table and just began with the activities...then she began looking at me and I looked at her and asked her if she wanted to put on some glue together or by herself, whether she wanted us to stick some fruit that she liked...but she only quietly answered "uh-huh" to everything. Then she took the fruit and put it there, and when I asked her if she wanted some glue she again quietly said - no. This girl really needed stimulation, so I took the brush... and only when I took it did she take one too, and we began to glue together

T: What could you have done? You stimulated her to do what you had planned? This opens the question - was it necessary? Did you need to insist on the activity of gluing?

S: No. I didn't need to at all. I saw that she really liked the shape of the apple. She would always glue the apple. I could have asked her what the shape of the apple was like, what the colour was like...she told me herself it felt soft in her hands... when I pointed at the peel of the apple and asked her what it was, whether it was apple peel, she said that it was... Maybe I should have talked to her more in this way. Like, focusing more on the fruit itself, not just the gluing.

T: For children, learning means holding something in their hand, touching, seeing, smelling and positioning it wherever they want in space. 
They can take everything out, put it all back one by one. They can also arrange it all on paper, which means that what is important for you to realize is that you can offer glue and everything else that you planned, but if the children show no interest in gluing things to cardboard, this does not mean you have failed, but that you have succeeded - because you are going along with the children's interests.

Our analysis of the transcripts indicate that, during the discussions conducted, effort was made to prepare students for the evaluation of their own actions and achievements, i.e. to train them to perform the process of (self-) reflection. The students' statements demonstrated a high level of self-critique: they openly discussed the less successful segments of their work and what they would change in their own actions. Most of them were already aware of their difficulties when conducting their activities, while most perceived them as an inability to cope with the given situation. For example: "I didn't know how to answer a specific question that the children asked., "How should I act when the children begin to push and shove?", "How to stop an activity", etc. The aforementioned suggests the conclusion that mutual learning, as promoted by the social constructivist approach to education, directly contributes to the development of (self-)reflection, i.e. self-reflective competencies among future teachers through the organization of discussions between students and teachers. Senge et al. (2003) defines dialogue as the free flow of thought between individuals by which new knowledge and mutual meaning are developed, and in which individuals are not opposed to each other but constantly and actively participate in an exchange of thoughts that aims to achieve the best possible educational practice.

\section{Concluding thoughts}

The post-activity discussions between the teachers and students were organized in order to prepare the students for their roles as reflective practitioners. With the acquisition of reflective competencies, the students prepare for the complexity and unpredictability of educational practice and how to understand it, while participation in mutual discussions brings to their awareness the importance of brainstorming in a group in order to better understand the problems that exist in practice and achieve better results at work.

We believe that the timely recognition and satisfaction of children's needs are of crucial importance to the education process. In order for students to be as competent in this area as possible, it is necessary to ensure that they 
complete a period of practice that will allow them to get involved "where the action is", and thus develop a greater sensitivity to the needs and interests of children. Likewise, we think that reflective practice, i.e. discussions with teachers and education practitioners after the completion of activities, can be of great assistance in helping students acquire the observation skills that will allow them to adapt to the children's needs instead of following a predetermined plan.

The next step that needs to be taken is to raise the students' awareness of the fact that an illusory consensus and the uncritical acceptance of others' opinions are not desirable forms of behaviour on the path to mutual learning. Likewise, it is necessary to encourage students to express differing perspectives on the problem being discussed, and to present this difference as an advantage instead of a flaw or threat. In order for discussion to truly lead to a better understanding of the educational reality and to develop the competencies of a (self-) reflective practitioner among students, it is vital to create an environment of mutual trust in which the students can, both between themselves and together with teachers and practitioners, openly question and discuss their views, values and convictions and the many ways in which they influence their educational practice. Finally, we wish to underscore that the professionalism of the teachers involved in initial teacher training within a modern education system also presupposes the constant re-examination of one's practice in order to improve it.

\section{References}

Beck, C., \& Kosnik, C. (2006). Innovations in Teacher Education: A Social Constructivist Approach. Albany: State University of New York Press.

Besson, B., Huber, J., Mompoint-Gaillard, P., \& Rohmann, S. (2014). The Professional Image and Ethos of Teacher. Strasbourg: Council of Europe.

Bruner, J. S. (2000). Kultura obrazovanja. Zagreb: Educa.

Dahlberg, G., \& Moss, P. (2006). Ethics and Politics in Early Childhood Education. London:

RoutledgeFalmer.

Elliott, J. (1998). The Curriculum Experiment, Meeting the Challenge of Social Change. Buckingham Philadelphia: Open University Press.

Fullan, M. (1993). Change Forces. London: The Falmer Press.

Fullan, M. (2007). The New Meaning of Educational Change, 4 th edition. New York and London: Teachers College Columbia University. Jančić-Komljen, M. (2013). (Samo)refleksivni praktičar: sociokonstruktivistički pristup u obrazovanju odgajatelja/(Self) reflective practitioner: socio-constructivist approach to teacher training.(Graduation Thesis, Faculty of Teacher Education, University of Rijeka). Rijeka: Učiteljski fakultet u Rijeci. Lepičnik-Vodopivec, J., \& Vujičić, L. (2010). The development of professional competencies: The 
educator as a reflective practitioner in tertiary education. Scientia paedagogica experimentalis. International Journal of Experimental Research, 47(1), 111-130.

Mac Naughton, G., \& Hughes, P. (2009). Doing Action Research in Early Childhood Studies. A step by step guide. New York: Open University Press.

Miljak, A. (1996). Humanistički pristup teoriji i praksi predškolskog odgoja. Velika Gorica, Zagreb: Persona.

Pešić, M. (2004). Pedagogija u akciji - metodološki priručnik. Beograd: Institut za pedagogiju i andragogiju.

Powell, E. (2005). Conceptualising and facilitating active learning: teachers' video-stimulated reflective dialogues. Reflective Practice, 6(3), 407-418.

Radulović, L., (2011). Obrazovanje nastavnika za refleksivnu praksu. Beograd: Filozofski fakultet. Rinaldi, C. (2006). In Dialogue with Reggio Emilia: listening, researching and learning. New York: Routledge.

Schoen, D. A. (1990). Educating the Reflective Practitioner: Toward a New Design for Teaching and Learning in the Professions. San Francisco: Jossey-Bass.

Senge, P. M., Kleiner, A., Roberts, C., Ross, R., Roth, G., \& Smith, B. (2003). Ples promjene. Izazovi u razvoju učécih organizacija. Zagreb: Mozaik knjiga.

Stoll, L., \& Fink, D. (200o). Mijenjajmo naše škole, Kako unaprijediti djelotvornost $i$ kvalitetu škola. Zagreb: Educa.

Šagud, M. (2006). Odgajatelj kao refleksivni praktičar. Petrinja: Visoka učiteljska škola u Petrinji. Vujičić, L., \& Đapić, K. (2009). Obrazovanje odgajatelja refleksivnog praktičara u kontekstu integracijskog pristupa kao načela rada s djecom rane i predškolske dobi. In L. Vujič̌ć \& M. Duh (Eds.), Interdisciplinarni pristup učenju put ka kvalitetnijem obrazovanju djeteta/Interdisciplinary Approach to Teaching a Path to More Quality Education of Children (pp. 253-271). Rijeka: Učiteljski fakultet Sveučilišta u Rijeci; Maribor: Pedagoški fakultet Sveučilišta u Mariboru; Rijeka: Zambelli. Vujičić, L., Tatalović Vorkapić, S., \& Boneta, Ž. (2012). Istraživanje odgojno-obrazovne prakse: dominantna strategija profesionalnog razvoja odgajatelja. In I. Pehlić \& A. Hasanagić (Eds.), Teorija i praksa ranog odgoja/Theory and Practice of Early Education (pp. 345-363). Zenica: Odsjek za predškolski odgoj i obrazovanje Islamskog pedagoškog fakulteta Univerziteta u Zenici. Vujičić, L., \& Miketek, M. (2014). Children’s Perspective in Play: Documenting the Educational Process. Croatian Journal of Education, 16(1), 143-159.

Zaclona, Z. (2007). Teacher`s reflection and pedagogical competency. In N. Babić (Ed.), Kompetencije i kompetentnost učitelja/Competences and Teacher Competence (pp. 501-511). Osijek: Sveučilište J.J. Strossmayera. 


\section{Biographical note}

Lidija Vujıčıć, Ph.D., is a pedagogue and an Associate Professor at the Faculty of Teacher Education in Rijeka. Her scientific interests include: early and preschool education; new paradigm of the child and childhood, the culture of educational institutions; (co)construction of curriculum, initial education of preschool teachers; professional development of teachers/ preschool educators; action research. She teaches at the postgraduate doctoral study of pedagogy, held at the Faculty of Arts and Social Studies in Rijeka. She is currently leading the project entitled "The Culture of Educational Institutions as a Factor in the (Co)construction of Knowledge."

ŽELJKo Boneta, Ph.D., is a sociologist and a assistant professor at the Faculty of Teacher Education in Rijeka. His scientific interests include: sociology of religion, sociology of childhood, modernization theories and processes, ethnic relations and intercultural education. He teaches at the postgraduate doctoral study of pedagogy, held at the Faculty of Humanities and Social Sciences in Rijeka. He is currently enrolled the project entitled "The Culture of Educational Institutions as a Factor in the (Co)construction of Knowledge."

ŽELJKA IVKOVIć is a sociologist and an assistant at the Faculty of Teacher Education in Rijeka and a doctoral candidate at Department of Sociology at Faculty of Humanities and Social Sciences in Zagreb. Her scientific interests include: sociology of childhood, economic activities of children, feminisation of teacher profession, ethnic relations and collective memory. She is currently enrolled in the project entitled "The Culture of Educational Institutions as a Factor in the (Co)construction of Knowledge." 